\author{
ks. Wiesław Pieja ${ }^{1}$
}

Tarnowska Szkoła Wyższa

\title{
Aktualność nauczania Jana Pawła II na temat błędu antropologicznego
}

\section{Streszczenie}

Poprawnie zbudowana etyka jest możliwa jedynie na fundamencie integralnej antropologii. Integralna antropologia zakłada godność osoby ludzkiej, czyli proponuje wizję człowieka wraz z duszą i ciałem, oraz człowieka odkupionego przez Jezusa Chrystusa. Nie zawsze takie przesłanki towarzyszą antropologii ludzkiej. Pojawia się wtedy tzw. błąd antropologiczny, który jest błędnym myśleniem o człowieku. Jan Paweł II jako pierwszy posługuje się pojęciem błędu antropologicznego. Czyni to $\mathrm{w}$ wielu miejscach swego nauczania. Celem naszej publikacji jest ukazanie błędu antropologicznego w kontekście filozoficznym, społecznym i kulturowym, ukazanym przez Jana Pawła II, oraz aktualizacja jego interpretacji. Byłoby rzeczą wskazaną, aby podjętą przez Jana Pawła II kwestię błędu antropologicznego prześledzić w publikacjach jego następców - papieża Benedykta XVI i papieża Franciszka.

Słowa kluczowe: błąd antropologiczny, Jan Paweł II, osoba ludzka, godność osoby

\section{Summary}

Timeliness of Teaching of John Paul II on the Issue of Anthropological Error

Correctly built ethics is possible to be established only on the foundation of integral anthropology. Integral anthropology presupposes the dignity of the human being, that is, it shows a vision of a man, with his soul and his body, and a man redeemed by Jesus Christ. Such premises do not always accompany human anthropology. Then, the so-called "anthropological error" appears, which is an attempt to mistaken thinking about a man. John Paul II was the first to use the concept of the anthropological error. He mentioned this topic in many aspects

1 Ks. Wiesław Pieja (OCID: 0000-0002-7097-3639) - doktor teologii moralnej na Uniwersytecie Jana Pawła II w Krakowie. Studia Specjalistyczne na KUL z zakresu psychoterapii dla duchowieństwa, teolog, duszpasterz, wykładowca w Tarnowskiej Szkole Wyższej, należy do Stowarzyszenia Teologów Moralistów, proboszcz parafii pw. Trójcy Przenajświętszej w Okocimiu. E-mail: pieja1@wp.pl. 
of his teaching. The message of my publication is a multifaceted discussion of the anthropological error in philosophical, social and cultural contexts, presented by John Paul II, and its update.

Keywords: anthropological error, John Paul II, human being, human dignity

Jan Paweł II bardzo mocno wpisuje się w dziedzictwo chrześcijańskie europejskiego kontynentu i w nauczanie całego Kościoła. Tożsamość Europy od wieków budowały wartości ludzkie i chrześcijańskie, a u podstaw tych wartości stał człowiek-osoba i Odkupienie w Jezusie Chrystusie. W ostatnim czasie Europa zaczyna stopniowo odchodzić od tych fundamentów i wartości, z których wyrasta ${ }^{2}$. Pozbywa się swojego dziedzictwa chrześcijańskiego, traci swoją tradycję i kulturę. Przyczyną takiego stanu jest błąd antropologiczny w wymiarze filozoficznym, indywidualnym, społecznym i kulturowym.

Jan Paweł II w Centissimus annus posłużył się pojęciem „błędu antropologicznego". Po ukazaniu się tego dokumentu pojawiły się pierwsze komentarze, publikacje i organizowno na ten temat sympozja. Tym pojęciem również zajęło się wielu teologów w sposób merytoryczny³.

Ojciec Święty w powyższym dokumencie mówi wprost o błędzie antropologicznym socjalizmu jako formacji społeczno-ekonomiczno- politycznej. Podczas Międzynarodowego Sympozjum Metafizycznego, które odbyło się 12 grudnia 2002 roku w Lublinie, ukazano i podkreślono, że błąd ten, mimo upadku socjalizmu, występuje także w różnych obszarach współczesnej kultury. Błąd antropologiczny polega również na tym, że przyjmuje się fałszywą koncepcję człowieka, a to z kolei prowadzi do formułowania mylnych zasad postępowania. Działanie oparte na nierozumieniu natury człowieka prędzej czy później musi doprowadzić do kryzysu budowanej na nim kultury ${ }^{4}$.

2 J.A. Kłoczowski, Wartości duchowe w zjednoczonej Europie, Katowice 2004, s. 12.

3 P. Jaroszyński, Kultura chrześcijańska szansą uniknięcia błędu antropologicznego, w: Błąd antropologiczny, red. A. Maryniarczyk, K. Stępień, Lublin 2003, s. 395-398; Komunizm, w: Jan Paweł II. Encyklopedia nauczania społecznego, red. A. Zwoliński, Radom 2003, s. 239; H. Seweryniak, Apologia pokolenia JP II, Płock 2006, s. 25.

4 V Międzynarodowe Sympozjum Metafizyczne pt. „Błąd antropologiczny” i jego konsekwencje w kulturze, odbyło się 12 grudnia 2002 r. w Lublinie, zob. „Ethos” 2003 nr 61-62, s. 469-483. 
Naszym głównym celem będzie ukazanie kwestii, którą Jan Paweł II nazwał błędem antropologicznym. Powszechnie wiadomo, że poprawnie zbudowana etyka jest możliwa jedynie na fundamencie integralnej antropologii. Dlatego wskazane jest, aby na początku przeprowadzić wstępną analizę błędnego myślenia o człowieku.

\section{Filozoficzne zakorzenienie błędnego myślenia o człowieku}

Poprawnie zbudowana etyka jest możliwa jedynie na fundamencie integralnej antropologii. Sam rdzeń tzw. „błędu antropologicznego tkwi w tym, że człowiek widziany jest i traktowany fragmentarycznie. $\mathrm{Na}$ takie widzenie człowieka wpływają kierunki filozoficzne, które niosą ze sobą niszczenie właściwego obrazu człowieka w jego odniesieniu do Boga Stwórcy i Zbawcy. Błąd antropologiczny - to inaczej błędna wizja człowieka, nie do końca spójna i scalona. Jest to błąd, który na podobieństwo komórek nowotworowych jest rozsiewany w kulturze, w moralności, w duchowości medialnej, w różnych sferach wychowania, a także w budowaniu motywacji zachowań ludzkich. Jego główną inspiracją jest humanizm horyzontalno-ateistyczny. Przedstawicielami tego kierunku są tak znani myśliciele, jak Karol Marks, Jean-Paul Sartre czy Ludwig Feuerbach. Według założeń tego prądu umysłowego, najważniejszymi miernikami człowieczeństwa jest skrajnie rozumiana wolność i tym samym ubóstwienie samego człowieka. Konsekwencją jest odrzucenie Boga.

Feuerbach, należący do lewicy heglowskiej, dokonał w swojej filozofii ubóstwienia człowieka. Zdaniem tego myśliciela, jeśli świadomość człowieka jest miejscem pojawienia się Boga, to należy ją przeanalizować i wówczas dojdzie się do przekonania, że Bóg jest jej wytworem. Bóg jest projekcją człowieka. To człowiek stworzył sobie Boga w swojej świadomości, jako rezultat swoich niespełnionych pragnień ${ }^{5}$.

Z powyższej wypowiedzi wynika, że wymiar osobowy został sprowadzony do wymiaru świadomościowego. Tak rozumiana świadomość zostaje uznana w wielu wymiarach kultury za kreatora rzeczywistości. Dla Marksa natomiast człowiek jest wyłącznie istotą społeczną, której potrzeby

5 I. Dec, Humanizmy i ich roszczenia w wyjaśnianiu człowieka, w: Błąd antropologiczny, red. A. Maryniarczyk, K. Stępień, Lublin 2003, s. 56-57. 
indywidualne mają charakter uboczny czy wtórny wobec pierwszeństwa potrzeb ogólnych, społecznych. Marks dokonał swoistej transformacji, polegającej na odrzuceniu niepowtarzalności jednostki - osoby na rzecz społeczeństwa ${ }^{6}$. Miało to $\mathrm{w}$ myśli XX wieku swoje zgubne następstwa w postaci rewolucji bolszewickiej. Następnym ogniwem w procesie deifikacji człowieka w imię negacji Boga jest myśl filozoficzna Sartre’a. Centralną ideą w jego antropologii jest wręcz ubóstwianie wolności. Filozof twierdzi, że człowiek jest z istoty swej samą wolnością i dlatego zdolny jest do bycia poza prawdą, i konsekwentnie także poza dobrem i złem. Sam staje się zdolny do ustanawiania nowych prawd i praw w porządku epistemologicznym oraz nowych wartości w porządku aksjologicznym. To wolność właśnie czyni go nadczłowiekiem, nadaje mu w porządku świadomości-wolności rangę samowystarczającego podmiotu. Zdaniem Sartre'a wszystko, co jest dziś na świecie - jest przeciwko Bogu. Twierdzi on, że sam Bóg ani nigdy nie istniał, ani też nie istnieje. Uważa, że człowiek jest absolutną wolnością, która pozbawiona jest wszelkich determinantów, także Boga, który kiedyś był uważany za jedną z nich. Dlatego człowiek jest na tym świecie dramatycznie i beznadziejnie sam. Nic ani nikt nie jest w stanie go zbawić. Nie dziwi więc fakt, iż Jan Paweł II w Ecclesia in Europa napisał:

Wydaje się bowiem, że czasy, w jakich żyjemy, i związane z nimi wyzwania to okres zagubienia. Tylu ludzi sprawia wrażenie, że są zdezorientowani, niepewni, pozbawieni nadziei, stan ducha wielu chrześcijan jest podobny. Liczne niepokojace oznaki pojawiły się na początku trzeciego tysiąclecia na horyzoncie kontynentu europejskiego, który, „choć jest pełen znaków i świadectw wiary, a jego społeczność niewątpliwie żyje w większej wolności i jest bardziej zjednoczona, odczuwa skutki spustoszenia, jakiego dawna i najnowsza historia dokonała w najgłębszych tkankach jej ludów, często rodząc rozczarowanie"7.

Stan zagubienia, samotności, pozbawienia nadziei, spustoszenia i rozczarowania współczesnego człowieka implikuje pytanie, na czym polega właściwe określenie błędu antropologicznego.

6 Kard. P. Poupard, Kościót i nowa Europa, „Znaki Czasu” 24 (1991), s. 3-8.

Jan Paweł II, Adhortacja Ecclesia in Europa, 7, Watykan 2003. 


\section{Próba określenia błędu antropologicznego}

Warto zatrzymać się nad faktem szerokiego opisywania błędu antropologicznego w Ecclesia in Europa. W adhortacji samo wyrażenie „błąd antropologiczny" nie występuje, ale znajdujemy w niej wiele szczegółowych analiz pozwalających na jego łatwe rozpoznanie. Mamy zatem do czynienia z pośrednią próbą określania tego błędu. Na uwagę zasługują numery 7 oraz 9 adhortacji. W numerze 9 czytamy:

Jedną z przyczyn gaśnięcia nadziei jest dążenie do narzucenia antropologii bez Boga $i$ bez Chrystusa. Taki typ myślenia doprowadził do tego, że uważa się człowieka za „absolutne centrum rzeczywistości, każąc mu w ten sposób wbrew naturze rzeczy, zająć miejsce Boga, zapominając o tym, że to nie człowiek czyni Boga, ale Bóg czyni człowieka. Zapomnienie o Bogu doprowadziło do porzucenia człowieka", i dlatego „nie należy się dziwić, jeśli w tym kontekście otworzyła się rozległa przestrzeń dla swobodnego rozwoju nihilizmu na polu filozofii, relatywizmu na polu teorii poznania i moralności, pragmatyzmu i nawet cynicznego hedonizmu w strukturze życia codziennego”. Europejska kultura sprawia wrażenie „milczącej apostazji" człowieka sytego, który żyje tak, jakby Bóg nie istniał.

Kluczowym zdaniem w przytoczonym fragmencie jest to, które mówi o narzuceniu ludziom antropologii bez Boga i bez Chrystusa. Widzimy, w jaki sposób odrzucenie Boga prowadzi do porzucenia człowieka. W kulturze szerzona jest absolutyzacja jednostki. To sam człowiek czyni siebie bogiem, określając siebie tym samym nie zwycięzcą, ale de facto ofiarą relatywizmu, nihilizmu, wszechobecnej konsumpcji oraz pragmatyzmu, a nawet hedonizmu. Konsekwencją takiego stanu rzeczy są różne współczesne ruchy parareligijne czy parafilozoficzne, takie jak New Age czy wiele odmian postmodernizmu. Łączy te ruchy i inspiracje to, że człowiek - świadomie albo nie - stwarza sobie iluzję religii lub stwarza sobie namiastkę religii ${ }^{9}$.

We współczesnym świecie, w którym celowo wykorzenia się Boga z życia całych społeczeństw, aby narzucić postmodernistyczny styl istnienia, wszelkie ruchy typu New Age ${ }^{10}$ w kulturze zyskują na atrakcyjności.

8 Jan Paweł II, Adhortacja Ecclesia in Europa, 9.

9 O.S. Rouvillois, New Age - kultura i filozofia, tłum. K. Mądel, K. Skorulski, Kraków 1996, s. 220 .

10 Por. O.S. Rouvillois, New Age - kultura i filozofia, dz. cyt., s. 260. 
Ich atrakcyjność jawi się przede wszystkim w postawieniu człowieka w centrum świata, którego jest on panem. Do tego wszystkiego dochodzi jeszcze nowa - niechrześcijańska - eschatologia, która skierowana jest na wyzwolenie człowieka i na tworzenie raju na ziemi. Utopijnie i manipulacyjnie - obiecuje się człowiekowi wyrwanie go z kręgu złego świata, pełnego wojen i nienawiści, i umieszczenie go w erze wiecznego pokoju i miłości.

Akcent położony wyłącznie na człowieka nie jest jednakże czymś pozytywnym, czymś, co powodowałoby jego rozwój moralny czy duchowy. Absolutyzacja człowieka zmierza do zaspokojenia wszelkich potrzeb ludzkich, niezależnie od ich wagi moralnej. Człowieczeństwo zostaje sprowadzone do wymiaru odczuwania przyjemności. Tylko to, co daje człowiekowi satysfakcję jest naprawdę wartościowe. Bóg to tylko dodatek, służący do zaspokajania tych potrzeb. „Religia w postmodernistycznym ujęciu ma dostarczać radosnych przeżyć" - taki jest hedonistyczny obraz religii, która ma objąć panowanie w świecie ponowoczesności. „Milcząca apostazja”, jak pisze w adhortacji Jan Paweł II, doprowadziła do zepchnięcia Boga, a tym samym Chrystusa, na margines życia wielu Europejczyków. Wiara zostaje pozbawiona swojego wymiaru społecznego, wspólnotowego, liturgicznego, a sprowadzona jedynie do wymiaru indywidualnego. Wiara ma być czymś wyłącznie prywatnym, zamkniętym w czterech ścianach domu. Rozbicie wspólnotowości, która jest nieodłącznym elementem konstytuującym religię, uderza w człowieka, pozbawiając go więzi z osobami i samym Bogiem. Człowiek zostaje sam w chaosie pojęć i marzeń, którym nadaje się jakieś namiastki duchowości. Nieuchronnie takie podejście prowadzi do zaprzeczenia, a w konsekwencji odrzucenia całej tradycji duchowej Europy, której korzenie są korzeniami chrześcijańskimi ${ }^{11}$. Numer 7 adhortacji trafnie definiuje sytuacje opuszczenia Boga przez człowieka:

Wśród wielu aspektów, szeroko zarysowanych również przy okazji Synodu, chciałbym przypomnieć utratę pamięci i dziedzictwa chrześcijańskiego, któremu towarzyszy swego rodzaju praktyczny agnostycyzm i obojętność religijna, wywołująca u wielu

Por. E. Gilson, Tomizm. Wprowadzenie do filozofii św. Tomasza z Akwinu, Warszawa 1998, s. 74 . 
Europejczyków wrażenie, że żyją bez duchowego zaplecza, niczym spadkobiercy, którzy roztrwonili dziedzictwo pozostawione im przez historię. Nie dziwią zatem zbytnio próby nadania Europie oblicza wykluczającego dziedzictwo religijne, a w szczególności głęboką duszę chrześcijańską, przez stanowienie praw dla tworzących ją ludów, w oderwaniu od ich życiodajnego źródła, jakim jest chrześcijaństwo [...] Wielu ludzi nie potrafi już łączyć ewangelicznego przesłania z codziennym doświadczeniem; [...] w wielu sferach publicznych łatwiej jest deklarować się jako agnostycy, niż jako wierzący [...] $]^{12}$.

Te słowa wyraźnie określają sytuację, z jaką mamy dziś do czynienia w Europie i ukazują sam rdzeń „błędu antropologicznego” nie tylko w jego etycznych wymiarach. Dlatego wskazane jest, abyśmy przeszli do analizy błędu w wymiarze społecznym.

\section{Społeczny wymiar błędu antropologicznego}

„Błąd antropologiczny” jest mylnym odczytaniem natury człowieka, jego roli w istniejącym świecie, ma swoje dalsze implikacje w większej zbiorowości, jaką stanowi społeczeństwo. Wynika ze złej, niepełnej próby zdefiniowania pojedynczej jednostki ludzkiej, dotyczy także całej zbiorowości ludzkiej, gdyż nie można oddzielić człowieka od reszty społeczeństwa, które on tworzy ${ }^{13}$. Wzmiankowany błąd ma więc swój wymiar społeczny.

Przyjrzyjmy się pierwszej kwestii, mianowicie błędowi indywidualizmu. Indywidualizm obecnie świeci tryumfy jako liberalna teoria społeczna ${ }^{14}$. Indywidualizm jawi się jako określony typ postaw i zachowań człowieka w danej społeczności. Człowiek sam narzuca sobie pewne cele. Zazwyczaj są naznaczone piętnem konsumpcji, hedonizmu, i ich osiąganie odbywa się na drodze pragmatyzmu.

Indywidualizm ujmuje człowieka jako jednostkę autonomiczną i autoteliczną, doskonałą, ukierunkowaną na obiektywny cel, jakim jest nieskończone Dobro. Społeczeństwo zostaje uznane jako dodatek dla jednostki ${ }^{15}$.

12 Jan Paweł II, Adhortacja Ecclesia in Europa, 7.

13 Por. J. Maritain, Człowiek i państwo, Kraków 1993, s. 7.

14 Por. J. Maritain, Człowiek i państwo, dz. cyt., s. 83.

15 Por. P. Skrzydlewski, Błąd antropologiczny w teoriach społecznych, w: Błąd antropologiczny, red. A. Maryniarczyk, K. Stępień, Lublin 2003, s. 223-224. 
W encyklice Evanglium vitae Jan Paweł II tak podsumowuje konsekwencje błędu antropologicznego zawartego w indywidualizmie:

Osłabienie wrażliwości na Boga i człowieka prowadzi nieuchronnie do materializmu praktycznego, co sprzyja rozpowszechnianiu się indywidualizmu, utylitaryzmu i hedonizmu. Ujawnia się tu także niezmienna prawdziwość słów Apostoła: „A ponieważ nie uznali za słuszne zachować prawdziwe poznanie Boga, wydał ich Bóg na pastwę na nic niezdatnego rozumu, tak że czynili to, co się nie godzi” (Rz 1, 28). W ten sposób wartości związane z „być” zostają zastąpione przez wartości związane z „mieć” ${ }^{16}$.

Jedynym celem, który się bierze pod uwagę, jest własny dobrobyt materialny. Tak zwana ,jakość życia jest interpretowana najczęściej lub wyłącznie w kategoriach wydajności ekonomicznej, nieuporządkowanego konsumpcjonizmu, atrakcji i przyjemności czerpanych z życia fizycznego, natomiast zapomina się o głębszych - relacyjnych, duchowych i religijnych - wymiarach egzystencji.

Drugą skrajnością w teoriach społecznych jest kolektywizm ${ }^{17}$. Jak określić kolektywizm? Warto przypomnieć dwa podejścia do niego, które są wytworem dwóch, odrębnych światopoglądów: liberalnego oraz komunistycznego ${ }^{18}$.

Wśród szczegółowych symptomów błędu antropologicznego Jan Paweł II wymienia wzrost „lęku” ludzi w kulturze Zachodu, wewnętrzna pustka, utrata sensu życia. Zauważa:

Jednym z wyrazów i owoców tej egzystencjalnej udręki jest zwłaszcza dramatyczny spadek liczby urodzeń, zmniejszenie liczby powołań do kapłaństwa i życia konsekrowanego, trudności w podejmowaniu definitywnych wyborów życiowych jeśli nie wprost rezygnacja - również w małżeństwie ${ }^{19}$.

16 Jan Paweł II, Encyklika Evanglium vitae, 23.

17 Omówienie krytyczne znajdziemy m.in. w G. Cottier, Osoba i demokracja, „Znaki Czasu” 24 (1991), s. 8-15.

18 W. Pieja, Społeczny wymiar błędu antropologicznego, w: W. Pieja, Moralna ocena obojętności religijnej, Kraków 2011, s. 123-131.

19 Jan Paweł II, Adhortacja Ecclesia in Europa, 8; por. I. Alberti, Śmiertelna pokusa ludzkości, „Znaki Czasu” 25 (1992), s. 4-8. 
Innym skutkiem błędu antropologicznego jest fragmentaryzacja ludzkiego życia i poczucie nieustannych kryzysów. Człowiek żyje „sytuacyjnie", zgodnie horacjańską carpe diem. Jan Paweł II tak to ocenia:

Jesteśmy świadkami rozpowszechnionej fragmentaryzacji egzystencji, dominuje poczucie osamotnienia, mnożą się podziały i kontrasty. Wśród innych przejawów tego stanu rzeczy w dzisiejszej sytuacji w Europie zauważa się niebezpieczne zjawisko kryzysów rodzinnych i słabości samej koncepcji rodziny, przeciągające się i powracające konflikty etniczne, odradzanie się pewnych postaw rasistowskich, a nawet napięcia międzyreligijne, egocentryzm izolujący jednostki i grupy od innych, narastanie powszechnej obojętności etycznej oraz gorączkowe zabieganie o własne interesy i przywileje. Wielu ludzi obawia się, że trwająca obecnie globalizacja, zamiast prowadzić ku większej jedności rodzaju ludzkiego, idzie za logiką, która spycha najsłabszych na margines i zwiększa liczbę ubogich na ziemi ${ }^{20}$.

W relacjach społecznych groźnym zjawiskiem jest brak podstawowego zaufania i solidarności międzyludzkiej ${ }^{21}$. Jan Paweł II pisze:

W powiązaniu z szerzącym się coraz powszechniejszym indywidualizmem dostrzega się coraz mniej przejawów solidarności międzyludzkiej, podczas gdy instytucje opieki pełnią godną uznania funkcję, zauważa się zanik poczucia solidarności, co powoduje, że ludzie - choć nie brakuje im tego, co konieczne pod względem materialnym - czują się bardziej osamotnieni, pozostawieni samym sobie, pozbawieni uczuciowego oparcia ${ }^{22}$.

Ostatecznie - zachowania wielu ludzi świadczą, że ich jedynym credo jest nihilizm egzystencjalny. Świadczy o tym choćby szeroka dyskusja o wychowaniu ${ }^{23}$. Myśliciele chrześcijańscy od lat wskazują na niebezpieczeństwo naruszenia stałego gruntu moralnego, który doprowadza do zwątpienia, poczucia „ciągłej niestabilności życiowej” wyobcowania oraz osamotnienia współczesnego człowieka. Człowiek jest traktowany jedynie jako przedmiot, a nie cel, podmiot działań. Takie przewartościowanie sensu istnienia człowieka i odwrócenie jego przeznaczenia, zresztą błędne, ma szerokie odbicie w kulturze ostatnich pięćdziesięciu lat.

\footnotetext{
20 Jan Paweł II, Adhortacja Ecclesia in Europa, 8.

21 Jan Paweł II, Adhortacja Ecclesia in Europa, 8.

22 Jan Paweł II, Adhortacja Ecclesia in Europa, 8.

23 Zob. „Ethos” 19/75 (2006) z. 3, s. 34, zeszyt zatytułowany 0 nowej edukacji.
} 


\section{Nośność kulturowa błędu antropologicznego}

Najważniejszym kontekstem, niejako podłożem rozszerzania się błędu antropologicznego jest kultura ostatnich pięćdziesięciu lat ${ }^{24}$.

Jan Paweł II, jakby wchodząc w to doświadczenie człowieka, stwierdza z mocą, że czasy zagubienia, skutki spustoszenia, które dokonuje najnowsza historia w tkankach ludów, często rodzi rozczarowanie.

W Europie od dziesięcioleci propaguje się pogląd, iż niewiara jest czymś naturalnym, na co też wskazują liczne badania empiryczne ${ }^{25}$. Co więcej - aż do naszych dni wiara jest traktowana albo w kategoriach absurdu ${ }^{26}$, albo co najwyżej - zgodnie z modą końca lat XX wieku - jako kwestia prywatna indywidualna, czyli jako „doświadczenie religijności pozainstytucjonalnej"27.

Współcześni Europejczycy żyją nieustannie pośród cudownych zabytków kultury chrześcijańskiej, mają do czynienia z literaturą piękną i sztuką inspirowaną od wieków przez Biblię: Objawienie i Nowy Testament, niestety jako odbiorcy kultury nie dostrzegają tego źródła. Dla młodego pokolenia Biblia coraz częściej przestaje być znanym i zrozumianym kodem kulturowym, który od czasów średniowiecza budował europejską tożsamość. Dlatego Jan Paweł II zanotował:

Oczywiście na kontynencie europejskim nie brak symboli chrześcijańskiej obecności, ale wraz z powolnym, stopniowo wkraczającym zeświecczeniem, powstaje niebezpieczeństwo, że staną się one jedynie pamiątkami przeszłości. Wielu ludzi nie potrafi już łączyć ewangelicznego przesłania z codziennym doświadczeniem, wzrasta trudność przeżywania osobistej wiary w Jezusa. W takim kontekście społecznym i kulturowym, w którym chrześcijańska koncepcja życia jest stale wystawiana na próbę i zagrożona, w wielu sferach publicznych łatwiej jest deklarować się jako agnostycy, niż jako wierzący. Odnosi się wrażenie, że niewiara jest czymś

24 Przykładem takiej analizy jest dwutomowe dzieło: V. Messori, Przemyśleć historię. Katolicka interpretacja ludzkiego losu, t. 1-2, Kraków 1998-1999.

25 Por. szerzej J. Pałysa, Na drodze wiary i niewiary. Trudności religijne dzisiejszego człowieka, „Communio" 8 (1988) nr 3, s. 3-24.

26 Por. E. Guibert-Sledziewski, Wiara w kategoriach absurdu, „Communio” 8 (1988), nr 3, s. 25-36.

27 Por. Th. Luckmann, Niewidzialna religia, Kraków 1996. 
naturalnym, podczas gdy wiara wymaga uwierzytelnienia społecznego, które nie jest ani oczywiste, ani przewidywalne ${ }^{28}$.

Europa, która pozbawia się swojego dziedzictwa chrześcijańskiego, pozbawia się - jak to ujął Jan Paweł II - „duchowego zaplecza”, które od wielu wieków nadawało kontynentowi europejskiemu jego duchowe oblicze. Chrześcijańska duchowość to duchowość personalistyczna, w której centrum jest człowiek, ale zawsze w relacji do Boga, do Chrystusa. Taka duchowość ukształtowała całą cywilizację naszego kręgu kulturowego. Wyparcie się tej tradycji jest swoistym samobójstwem, którego skutki są już odczuwane. O ile elity, mieniące się kreatorami współczesnych mód filozoficznych czy społecznych i narzucające określony styl życia, są w zupełności pochłonięte wizją zniszczenia i odrzucenia chrześcijaństwa z całym jego dorobkiem kulturowym ${ }^{29}$.

Tymczasem, na co zwracają uwagę dokumenty Soboru Watykańskiego II, „stworzenie bez Stworzyciela zanika”30, a bez Boga pozostają tylko ruiny ludzkiej moralności ${ }^{31}$.

28 Jan Paweł II, Adhortacja Ecclesia in Europa, 7.

29 Warto też przypomnieć, że według Habermasa (przedstawiciel frankfurckiej szkoły filozoficznej), upłynął już czas chrześcijaństwa, dlatego nie jest ono już systemem narzucającym normy na świecie. Rozszerza się masowa ateizacja i „chrześcijański” dotychczas obywatel odmawia lojalności swojemu państwu, o tyle masy społeczeństwa, zręcznie poddawane manipulacji medialnej, niezbyt wyraziście sprzeciwiają się pomysłom głęboko nie tylko niechrześcijańskim, ale przede wszystkim głęboko nieludzkim, takim jak eutanazja, pedofilstwo, homoseksualizm itp. Można powiedzieć, że człowiek systematycznie poddawany jest swoistemu procesowi dechrystianizacji, który skutecznie prowadzi do dehumanizacji osoby ludzkiej. Likwidacja chrześcijaństwa z całym jego dorobkiem, to zamach na człowieka. Przesłanie ewangeliczne zawiera w sobie całkowitą prawdę o człowieku, sytuując osobę ludzką w centrum świata, ale poddaną prawom Stwórcy, definiującą człowieka jako istotę rozumną, ale nie stawiającą się „ponad Bogiem”, a nawet „przeciw Niemu”. To są dywagacje na temat poglądów i przemyśleń filozoficznych Habermasa, por. M. Lipowicz, Chrześcijańska dekonstrukcja ponowoczesności? Albo jak każdy znak może być odwrócony, „Kultura i Polityka” 2009 nr 6, s. 105-117, a także zob. W. Julian-Korab-Karpowicz, Habermas i (nie)świadomość tego, co zostało utracone, „Przegląd Filozoficzny. Nowa Seria” 21 (2012) nr 2 (28), s. 389-399.

30 Sobór Watykański II, Konstytucja duszpasterska o Kościele w świecie współczesnym Gaudium et spes, nr 30, w: Sobór Watykański II, Konstytucje, dekrety, deklaracje, tekst polski, nowe tłum., red. M. Przybył, Poznań 2002, s. 547-548.

31 Jan Paweł II, Bez Boga pozostają ruiny ludzkiej moralności, w: Jan Paweł II, Dekalog. Czwarta Pielgrzymka do Ojczyzny, Pelpin 1991, s. 28. 
Aby nie popełniać błędu antropologicznego w wymiarze indywidualnym i społecznym, należy powrócić do dziedzictwa nauczania Jana Pawła II, w którym na plan pierwszy wysuwa się problem godności ludzkiej oraz odpowiedzialności człowieka za dzieło stworzenia i odkupienia. Myśl ta jest bardzo bliska papieżowi Franciszkowi, była też istotna w nauczaniu jego poprzednika Benedykta XVI.

\section{Zakończenie}

Celem naszej publikacji było ukazanie kwestii, którą Jan Paweł II nazwał błędem antropologicznym. Byłoby interesujące przedstawić, jak kwestię błędu antropologicznego widzieli następcy Jana Pawła II Benedykt XVI i Franciszek - którzy kontynuują jego nauczanie.

Pojęcie błędu antropologicznego posłużyło Janowi Pawłowi II do wskazania na błędną wizję człowieka, nie do końca spójną, która niestety jest powielana w kulturze, moralności, duchowości medialnej i w sferze wychowania. Owa wizja człowieka wynika z fałszywych założeń niektórych prądów filozoficznych, które stawiają człowieka przed Bogiem. Przyjęcie takiej wizji sprawia, że czasy, w jakich żyjemy, i związane z nimi wyzwania to okres zagubienia. Tylu ludzi czuje się dzisiaj zdezorientowanymi, niepewnymi, pozbawionymi nadziei, zwiększa się ich flustracja. Są to skutki spustoszenia, jakie najnowsza historia dokonała w najgłębszych tkankach ludów, często rodząc głębokie rozczarowanie. Niewłaściwie ujęta antropologia bowiem prowadzi do niszczenia obrazu Boga w człowieku, a to z kolei prowadzi do zagubienia człowieka.

Współczesna kultura sprawia wrażenie milczącej apostazji. Towarzyszy temu praktyczny agnostycyzm i obojętność religijna, Europejczycy żyją bez duchowego zaplecza, niczym spadkobiercy, którzy roztrwonili dziedzictwo pozostawione im przez historię. „W wielu sferach publicznych, łatwiej jest im się deklarować, jako agnostycy, niż jako wierzący”32. Te słowa wyraźnie określają sytuację z jaką mamy dziś do czynienia w Europie i ukazują sam rdzeń „błędu antropologicznego” nie tylko w jego etycznych wymiarach, ale społecznych.

\footnotetext{
32 Jan Paweł II, Adhortacja Ecclesia in Europa, 7.
} 
Odpowiedzią na taką sytuację jest antropologia teologiczna, która podkreśla godność osoby ludzkiej. Poszanowanie godności ludzkiej zapobiega wszelkim kryzysom, a sam człowiek posiadający godność osoby przekształca ten świat nie jako bezwzględny eksploatator, ale rozumny jej władca. Tymi słowami, parafrazując nauczanie Jana Pawła II z Redemptor hominis, chcemy podkreślić, że aktualność nauczania Jana Pawła II jest mocno obecna w nauczaniu papieża Franciszka. U papieża Franciszka dochodzi jeszcze problem ekologii jako konsekwencja błędu antropologicznego.

Prawdziwy rozwój człowieka, jego odpowiedzialność za dzieło stworzenia, ma charakter moralny i pociąga za sobą pełne poszanowanie osoby ludzkiej. Osoba ludzka powinna być ukierunkowana na świat przyrody i powinna „brać pod uwagę naturę każdego bytu oraz ich wzajemne powiązanie w uporządkowany system" ${ }^{33}$. Dlatego postuluje się, by zdolność człowieka do przekształcenia rzeczywistości była rozwijana na podstawie pierwotnego przeznaczenia rzeczy, wyznaczonego jej przez Boga ${ }^{34}$.

\section{Bibliografia}

Dec I., Humanizmy $i$ ich roszczenia w wyjaśnianiu człowieka, w: Błąd antropologiczny, red. A. Maryniarczyk, K. Stępień, Lublin 2003, s. 49-72.

Franciszek, Laudato si', Kraków 2015.

Gilson E., Tomizm. Wprowadzenie do filozofii św. Tomasza z Akwinu, Warszawa 1998, s. 74.

Guibert-Sledziewski E., Wiara w kategoriach absurdu, „Communio” 8 (1988) nr 3, s. 25-36.

Jan Paweł II, Encyklika Sollicitudo rei socialis, Watykan 1987.

Jan Paweł II, Encyklika Redemptor hominis, Watykan 1979.

Jan Paweł II, Encyklopedia nauczania społecznego, red. A. Zwoliński, Radom 2003.

Jan Paweł II, Encyklika Evangelium vitae, Watykan 1995.

Jan Pawel II, Adhortacja Ecclesia in Europa, Watykan 2003.

Jaroszyński P., Kultura chrześcijańska szansa uniknięcia błędu antropologicznego, w: Błąd antropologiczny, red. A. Maryniarczyk, K. Stępień, Lublin 2003, s. 242-245.

Kłoczowsk J.A.i, Wartości duchowe w zjednoczonej Europie, Katowice 2004, s. 12.

33 Jan Paweł II, Encyklika Solicitudo rei socialis (30.12.1987), 34, https://opoka.org.pl/ biblioteka/W/WP/jan_pawel_ii/encykliki/sollicitudo.html (23.02.2020).

34 Franciszek, Laudato si', 5, Kraków 2015. 
Korab-Karpowicz W.J., Habermas i (nie)świadomość tego, co zostało utracone, „Przegląd Filozoficzny. Nowa Seria" 21 (2012) nr 2 (28), s. 389-399.

Lipowicz M., Chrześcijańska dekonstrukcja ponowoczesności? Albo jak każdy znak może być odwrócony, „Kultura i Polityka” 2009 nr 6, s. 105-117.

Luckmann Th., Niewidzialna religia, Kraków 1996.

Messori V., Przemyśleć historię. Katolicka interpretacja ludzkiego losu, t. 1-2, Kraków 1998-1999.

Pałysa J., Na drodze wiary i niewiary. Trudności religijne dzisiejszego człowieka, „Communio" 8 (1988) nr 3, s. 3-24.

Pieja W., Moralna ocena obojętności religijnej, Kraków 2011.

Poupard P. kard, Kościół i nowa Europa, „Znaki Czasu” 24 (1991), s. 3-8.

Rouvillois. O.S., New Age - kultura i filozofia, tłum. K. Mądel, K. Skorulski, Kraków 1996, s. 220.

Seweryniak H., Apologia pokolenia JP II, Płock 2006.

Sobór Watykański II, Konstytucja duszpasterska o Kościele w świecie współczesnym Gaudium et spes, w: Sobór Watykański II, Konstytucje, dekrety, deklaracje, tekst polski, nowe tłum., red. M. Przybył, Poznań 2002, s. 526-606.

Skrzydlewski P., Błąd antropologiczny w teoriach społecznych, w: Bład antropologiczny, red. A. Maryniarczyk, K. Stępień, Lublin 2003, s.469-483. 